\title{
Erratum to: Handling Missing Data in Within-Trial Cost- Effectiveness Analysis: A Review with Future Recommendations
}

\author{
Andrea Gabrio $^{1}$ Alexina J. Mason ${ }^{2} \cdot$ Gianluca Baio $^{1}$
}

Published online: 8 May 2017

(c) The Author(s) 2017. This article is an open access publication

\section{Erratum to: PharmacoEconomics Open \\ DOI 10.1007/s41669-017-0015-6}

Reference 5, which reads:

5. Manca $P$, Palmer S. Handling missing values in cost effectiveness analyses that use data from cluster randomized trials. Appl Health Econ Health Policy. 2006;4:65-75.

Should read:

5. Manca A, Palmer S. Handling missing data in patientlevel cost-effectiveness analysis alongside randomised clinical trials. Appl Health Econ Health Policy. 2005;4:65-75.

Open Access This article is distributed under the terms of the Creative Commons Attribution-NonCommercial 4.0 International License (http://creativecommons.org/licenses/by-nc/4.0/), which permits any noncommercial use, distribution, and reproduction in any medium, provided you give appropriate credit to the original author(s) and the source, provide a link to the Creative Commons license, and indicate if changes were made.

The online version of the original article can be found under doi:10.1007/s41669-017-0015-6.

Andrea Gabrio

andrea.gabrio.15@ucl.ac.uk

1 Department of Statistical Science, University College London, 1-19 Torrington Place, London WC1E 7HB, UK

2 Department of Health Services Research and Policy, London School of Hygiene and Tropical Medicine, 15-17 Tavistock Place, London WC1H 9SH, UK 